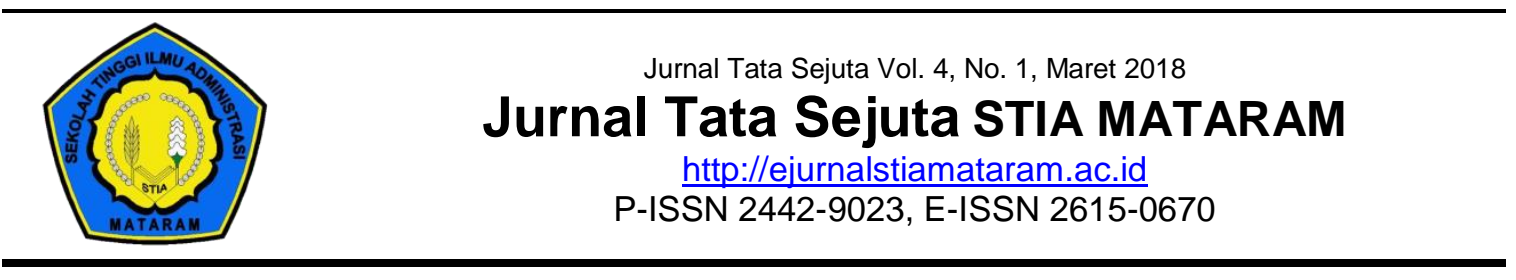

\title{
IMPLEMENTASI KEBIJAKAN ALOKASI DANA DESA DI DESA MARGASARI KECAMATAN MARGASARI KABUPATEN TEGAL
}

\author{
Yuni Kurniasih ${ }^{1}$, Hardi Warsono², Budi Puspo Priyadi ${ }^{3}$ \\ 1 Universitas Diponegoro
}

\begin{tabular}{l} 
Info Artikel \\
\hline Sejarah Artikel: \\
Diterima: 1 Maret 2018 \\
Disetujui: 21 Maret 2018 \\
Dipublikasikan: 30 Maret \\
2018 \\
\hline Kata Kunci: \\
Alokasi Dana Desa, \\
Implementasi, \\
Kebijakan
\end{tabular}

\section{Abstrak}

Alokasi Dana Desa adalah dana yang dialokasikan oleh Pemerintah Kabupaten Tegal untuk desa, yang bersumber dari bagian dana perimbangan keungan pusat dan daerah yang diterima oleh kabupaten. Alokasi Dana Desa sebagai salah satu sumber pendapatan desa diharapkan mampu membiayai berbagai pembangunan di desa sehingga dapat meningkatkan kesejahteraan masyarakat setempat. Dana dari kabupaten diberikan langsung kepada desa untuk dikelola oleh Pemerintah Desa.Penelitian ini bertujuan untuk mengetahui bagaimana implementasi Kebijakan Alokasi Dana Desa di Desa Margasari Kecamatan Margasari Kabupaten Tegal dan menganalisis faktor-faktor apa saja yang mempengaruhinya. Penelitian ini menggunakan metode penelitian kualitatif deskriptif. Hasil penelitian menunjukkan bahwa implementasi Kebijakan Alokasi Dana Desa di Desa Margasari belum menunjukkan hasil yang efektif. Hal ini bisa dilihat dari beberapa aspek implementasi kebijakan yang belum dijalankan dengan optimal seperti keterlibatan masyarakat dalam perencanaan ADD, pelaksanaan tupoksi tim koordinasi ADD tingkat kecamatan dan tingkat kabupaten, kesesuaian alokasi dengan pedoman, pelaporan dan pertanggungjawaban, dan kemanfaatan ADD untuk kemandirian desa. Faktor-faktor yang mempengaruhi implementasi seperti komunikasi, sumber daya, disposisi pelaksa dan struktur birokrasi juga belum berjalan dengan baik. Berdasarkan kesimpulan tersebut, peneliti merekomendasikan kepada para pelaksana mengenai perlunya komitmen yang tinggi dan memanfaatkan dukungan sumber daya finansial yang ada secara maksimal sehingga apa yang menjadi tujuan dari kebijakan ini dapat tercapai.

\section{THE IMPLEMENTATION OF VILLAGE ALLOCATION FUND POLICY IN MARGASARI VILLAGE SUB DISTRICT MARGASARI TEGAL DISTRICT}

\footnotetext{
Keywords:

Village Allocation

Fund,

Implementation,

Policy
}

\begin{abstract}
Village Allocation Fund is a fund allocated by the Government for village in Tegal regency, which rises from the central and balance financial of fund received by district area. The Village Fund Allocation as one of village income source is expected to finance various development programme in the village so that it can improve the prosperity of the local community. Funds from districts are provided directly to villages to be managed by the Village Government. This research was meant to find out how the implementation of village
\end{abstract}


allocation fund policy in Margasari village and knowing the influence factors of this implementation. This research using qualitative research methods. The results showed that the implementation of village allocation fund policy are still less effective that is seen from the precision implementation aspects such as society participation in planning process, performance of implementers, compatibility allocation with regulation, accountability of Village Allocation Fund, and benefit of Village Allocation Fund for village autonomy. The factors that influence the implementation such as communication, resource policy, disposition of the implementor and bureaucratic structure are still less optimal too. Based on these conclusions, the researcher recommend to the implementation agency should have high commitment and take maximal advantages of financial sources in order to achieve the purpose of this policy.

(C) 2018 Sekolah Tinggi IImu Administrasi Mataram

Alamat korespondensi:

fisip@undip.ac.id, k.yunikurniasih@gmail.com

\section{PENDAHULUAN}

\section{A. Latar Belakang}

Pembangunan daerah merupakan bagian integral dari pembangunan nasional yang bertujuan untuk meningkatkan kapasitas pemerintahan daerah dalam memberikan pelayanan prima kepada masyarakat agar tercipta kemandirian daerah dan pemberdayaan masyarakat. Kemandirian daerah bertumpu pada pemberdayaan potensi lokal yang mana kemandirian tersebut harus dimulai dari level pemerintahan di tingkat paling bawah, yaitu desa. Anggaran pembangunan secara khusus dicantumkan dalam APBD untuk pembangunan wilayah pedesaan, yakni dalam bentuk Alokasi Dana Desa (ADD).

Alokasi Dana Desa adalah dana yang dialokasikan oleh Pemerintah Kabupaten Tegal untuk desa yang bersumber dari bagian dana perimbangan keuangan pusat dan daerah yang diterima oleh kabupaten. Alokasi Dana Desa sebagai salah satu sumber pendapatan desa diharapkan mampu membiayai berbagai pembangunan di desa sehingga dapat meningkatkan kesejahteraan masyarakat setempat.

Adapun permasalahan pada Kebijakan Alokasi Dana Desa di Desa Margasari Kecamatan Margasari Kabupaten Tegal yang telah berjalan selama ini yaitu kemampuan pengelola alokasi dana desa baik dari unsur pemerintah desa maupun lembaga kemasyarakatan di desa dalam perencanaan dan pengendalian kegiatan yang belum baik. Tidak diikutsertakannya seluruh komponen masyarakat dalam musyawarah penggunaan ADD. Perencanaan 
ADD dan pengalokasiannya sebagian besar dilakukan oleh kepala desa dan bendahara umum desa saja, belum melibatkan aspirasi masyarakat seperti yang tercantum dalam Peraturan Bupati Tegal Nomor 5 Tahun 2015.

Selain itu, ada indikasi kurangnya sosialisasi kebijakan ADD sampai tingkat pelaksana di desa. Sosialisasi Kebijakan ADD telah disampaikan kepada Tim Koordinasi Tingkat Kecamatan dan Tim Pelaksana Tingkat Desa. Namun, sosialisasi hanya dihadiri oleh perwakilan Tim Pelaksana Tingkat Desa sehingga ada kemungkinan terjadi bias dalam pemahaman ketika kebijakan harus diimplementasikan di desa.

Sering terjadi keterlambatan penyusunan dokumen laporan pertanggungjawaban yang mengakibatkan terlambatnya pencairan ADD tahap selanjutnya. Laporan realisasi pelaksanaan ADD semester pertama seharusnya disampaikan akhir bulan Juli tahun berjalan namun kenyataannya bulan Agustus akhir - Oktober awal SPJ baru dilaporkan kepada pihak kecamatan. Demikian pula dengan laporan akhir tahun yang seharusnya disampaikan paling lambat pada akhir bulan Januari tahun berikutnya namun keadaan di lapangan laporan akhir tahun disampaikan bulan Februari-April tahun berikutnya.

Permasalahan selanjutnya adalah rendahnya Pendapatan Asli Desa dibandingkan dengan Alokasi Dana Desa yang diterima. Hal ini dikhawatirkan akan menimbulkan ketergantungan desa terhadap dana transfer dari pemerintah daerah maupun pemerintah pusat.

Berdasarkan permasalahan tersebut penulis merasa perlu untuk menganalisis secara mendalam bagaimana implementasi Kebijakan Alokasi Dana Desa di Desa Margasari Kecamatan Margasari Kabupaten Tegal. Dalam implementasi kebijakan publik, satu hal yang paling penting adalah implementasi kebijakan harus dapat menampilkan keefektifan dari kebijakan itu sendiri.

\section{B. Tujuan}

1. Untuk menjelaskan pelaksanaan Kebijakan Alokasi Dana Desa di Desa Margasari Kecamatan Margasari Kabupaten Tegal.

2. Untuk mengidentifikasi dan menganalisis faktor pendorong dan faktor penghambat pelaksanaan Kebijakan Alokasi Dana Desa di Desa Margasari Kecamatan Margasari Kabupaten Tegal.

3. Untuk merumuskan upaya optimalisasi pelaksanaan Kebijakan Alokasi Dana Desa di Desa Margasari Kecamatan Margasari Kabupaten Tegal. 


\section{Teori}

\section{Administrasi Publik}

Administrasi publik menurut Chandler dan Plano dalam Keban (2008:3) adalah proses dimana sumber daya dan personel publik diorganisir dan dikoordinasikan untuk memformulasikan, mengimplementasikan, dan mengelola keputusan-keputusan dalam kebijakan publik. Administrasi publik merupakan seni dan ilmu yang ditujukan untuk mengatur public affairs dan melaksanakan berbagai tugas yang telah ditetapkan.

\section{Kebijakan Publik}

Kebijakan publik menurut James A. Enderson dalam Subarsono (2009:2-3) yaitu sebagai kebijakan yang ditetapkan oleh badan-badan dan aparat pemerintah. Walaupun disadari bahwa kebijakan publik dapat dipengaruhi oleh para aktor dan faktor dari luar pemerintah. Pilihan kebijakan yang dibuat oleh pejabat atau badan pemerintah dalam bidang tertentu, misalnya bidang pendidikan, politik, ekonomi, pertanian, industri, pertanahan, dan sebagainya.

\section{Implementasi Kebijakan Publik}

Implementasi merupakan suatu proses yang dinamis, dimana pelaksana kebijakan melakukan suatu aktivitas atau kegiatan, sehingga pada akhirnya akan mendapatkan suatu hasil yang sesuai dengan tujuan kebijakan itu sendiri. Berbagai regulasi dan kebijakan yang telah dibuat oleh pemerintah tidak akan mencapai tujuan yang efektif dan efisien apabila tidak adanya implementasi atau pelaksanaan dari kebijakan itu sendiri.

Untuk dapat mengkaji dengan baik suatu implementasi kebijakan publik perlu diketahui variable atau faktor-faktor yang berpengaruh penting terhadap implementasi kebijakan serta guna penyederhanaan pemahaman, maka digunakan model-model implementasi kebijakan publik. Model implementasi kebijakan publik yang dijadikan acuan untuk melakukan penelitian ini adalah model implementasi kebijakan dengan perspektif top-down oleh George C. Edward III. Menurut George C. Edward III terdapat empat variabel yang mempengaruhi kinerja suatu implementasi kebijakan publik, yaitu komunikasi, sumber daya, disposisi pelaksana, dan struktur birokrasi.

Hal. 28 dari $\mathbf{8 1}$ 


\section{METODE PENELITIAN}

Peneliti menggunakan tipe penelitian deskriptif dengan pendekatan kualitatif. Informan dalam penelitian ini adalah Kabid Administrasi Pemerintahan Desa Dispermades Kabupaten Tegal, Kasi Pemberdayaan Masyarakat Desa Kecamatan Margasari, Kepala Desa Margasari, Bendahara Umum Desa Margasari, Ketua Tim Pelaksana ADD Desa Margasari, dan Tokoh Masyarakat Desa Margasari.

Jenis data yang digunakan yaitu data yang berbentuk teks dan data yang berbentuk kata-kata. Adapun sumber data terdiri dari sumber data primer yang berasal dari wawancara terhadap informan dan sumber data sekunder yang berasal dari dokumen, buku, data statistik, laporan dan lain-lain yang berhubungan dengan penelitian ini.

Teknik Pengumpulan data melalui observasi, wawancara, dan studi kepustakaan. Data yang diperoleh dari informan selanjutnya akan dianalisis secara sistematis dengan melakukan tiga langkah secara bersamaan yaitu kondensasi data, penyajian data, penarikan kesimpulan dan verifikasi. Penelitian ini menggunakan teknik pemeriksaan keabsahan data berdasarkan teknik triangulasi dengan sumber yang berarti membandingkan dan mengecek balik derajat kepercayaan suatu informasi yang diperoleh melalui waktu dan alat yang berbeda dalam penelitian kualitatif.

\section{HASIL DAN PEMBAHASAN}

Implementasi Kebijakan Alokasi Dana Desa di Desa Margasari Kecamatan Margasari Kabupaten Tegal

\section{Keterlibatan Masyarakat dalam Perencanaan ADD}

Masyarakat Desa Margasari memiliki kesadaran untuk turut hadir dan aktif dalam kegiatan Musrenbangdes dalam rangka pembahasan perencanaan penggunaan ADD. Kegiatan musyawarah pembangunan ini dilaksanakan untuk menyerap aspirasi masyarakat desa tentang kegiatan yang akan dilakukan pada program tersebut. Namun, Musyawarah Desa dalam rangka untuk membahas perencanaan pengelolaan ADD belum sepenuhnya melibatkan seluruh unsur elemen masyarakat.

Proses perencanaan juga tidak dilakukan secara partisipatif dan terbuka karena jumlah dana ADD yang dialokasikan untuk masing-masing lembaga 
kemasyarakatan telah ditentukan terlebih dahulu oleh perangkat desa. Hal ini tentu menjadi sebuah kendala bagi lembaga masyarakat itu sendiri karena jumlah dana yang mereka terima bisa saja tidak sesuai dengan kebutuhan.

\section{Pelaksanaan Tupoksi Tim Koordinasi ADD}

Pendampingan kegiatan ADD di Desa Margasari dilaksanakan oleh Tim Koodinasi Kabupaten, Tim Koordinasi Kecamatan dan Tenaga Pendamping Profesional Desa. Kinerja Tim Koordinasi ADD Tingkat Kabupaten dinilai sudah sesuai dalam melaksanakan tupoksi dan koordinasinya.

Namun, Tim Koordinasi ADD Tingkat Kecamatan dan Tenaga Profesional Pendamping Desa kurang maksimal dalam melaksanakan tugasnya. Tim Koordinasi Tingkat Kecamatan kesulitan melaksanakan monitoring dan evaluasi pelaksanaan ADD dalam setiap proses tahapan kegiatan di desa-desa karena keterbatasan waktu dan tenaga. Kemudian untuk tugas menghimpun dan menyimpan salinan arsip Surat Pertanggungjawaban ADD dari desa, Tim Koordinasi Tingkat Kecamatan hanya menghimpun sampai tahun 2015 saja karena sudah tidak ada tempat untuk menyimpan arsip di kantor kecamatan.

\section{Kesesuaian Alokasi dengan Pedoman}

Jumlah ADD Kabupaten Tegal tahun 2017 sebesar Rp 120.521.520.000. Sedangkan jumlah ADD yang diterima oleh Desa Margasari yaitu sebesar Rp 521.924.635,17. Sasaran lokasi ADD adalah seluruh desa dalam wilayah Kabupaten Tegal dengan perhitungan jumlah alokasi dana sesuai dalam Peraturan Bupati Tegal Nomor 2 Tahun 2017.

ADD di Desa Margasari dialokasikan untuk penghasilan tetap kepala desa dan perangkat desa, operasional pemerintahan desa, tunjangan dan operasional BPD, insentif Rukun Tetangga dan Rukun Warga dan pembiayaan kegiatan pemberdayaan masyarakat lainnya. ADD di Desa Margasari lebih banyak dialokasikan untuk kegiatan-kegiatan pemberdayaan masyarakat seperti pemberdayaan perempuan, kewirausahaan, kepemudaan dan lain lain.

\section{Pelaporan dan Pertanggungjawaban ADD}

Mekanisme pelaporan penggunaan Alokasi Dana Desa di Desa Margasari adalah Kepala Desa menyampaikan laporan realisasi penggunaan ADD kepada Bupati melalui Camat setiap enam bulan dengan tembusan Kepala Dinas 
Pemberdayaan Masyarakat dan Desa. Namun, pelaporan penggunaan Alokasi Dana Desa di Desa Margasari tidak tepat waktu dan sering terlambat.

Pembinaan pengelolaan ADD di Desa Margasari dilakukan secara berjenjang mulai dari Tim Koordinasi Kecamatan sampai Tim Koordinasi Kabupaten. Upaya pembinaan dan pengawasan yang dilakukan diantaranya adalah mengadakan monitoring untuk mengetahui sejauh mana pelaksanaan ADD di Desa Margasari. Pengawasan pengelolaan ADD dilakukan oleh Inspektorat Kabupaten Tegal. Pengawasan tersebut hanya dilakukan pada tingkat kecamatan. Tim Pelaksana ADD Tingkat Desa hanya diminta untuk melengkapi laporan-laporan dan bukti-bukti administrasi terkait pengelolaan ADD di desanya.

\section{Kemanfaatan ADD untuk Kemandirian Desa}

ADD digunakan untuk mendanai penyelenggaraan pemerintahan desa, pelaksanaan pembangunan desa, pembinaan kemasyarakatan desa, pemberdayaan masyarakat desa, penghasilan tetap dan tunjangan Kepala Desa dan Perangkat Desa, operasional pemerintah desa, tunjangan dan operasional Badan Permusyawaratan Desa, dan insentif rukun tetangga dan rukun warga.

Selanjutnya mengenai tata cara pengadaan barang/jasa dalam kegiatan ADD dilakukan secara swakelola dengan memaksimalkan penggunaan sumber daya alam berupa material atau bahan dari wilayah desa setempat. Hal itu dilaksanakan secara gotong royong dengan melibatkan partisipasi masyarakat setempat untuk memperluas kesempatan kerja dan pemberdayaan masyarakat di desa tersebut.

Secara keseluruhan tingkat partisipasi swadaya gotong royong masyarakat di desa-desa di wilayah Kabupaten Tegal masih rendah karena kondisi perekonomian masyarakat yang kurang mendukung dimana sebagai besar penduduk bermatapencaharian sebagai petani dan buruh tani. Partisipasi lebih bersifat gotong royong menyumbangkan tenaga dan pikiran untuk merencanakan pembangunan fisik di desa. Dengan adanya ADD dan bantuan keuangan lain semakin membuat partisipasi swadaya masyarakat rendah karena masyarakat bergantung pada dana bantuan keuangan yang diterima.

Faktor Pendukung dan Faktor Penghambat Implementasi Kebijakan Alokasi Dana Desa di Desa Margasari Kecamatan Margasari Kabupaten Tegal 


\section{Komunikasi}

Komunikasi yang dilakukan dalam implementasi kebijakan Alokasi Dana Desa di Desa Margasari dinilai masih kurang maksimal. Intensitas sosialisasi kebijakan ADD masih sangat rendah karena hanya dilakukan satu kali pada tingkat kecamatan saja sedangkan di desa tidak ada sosialisasi tentang kebijakan ADD kepada masyarakat secara luas.

Terkait penjelasan atau materi yang disampaikan baik oleh Tim Koordinasi Tingkat Kabupaten maupun Tim Koordinasi Tingkat Kecamatan tidak terdapat perbedaan, penyampaian perintah-perintah kebijakan ADD dapat dikatakan konsisten sampai ke tingkat desa.

Adapun materi tentang kebijakan ADD secara umum dapat dipahami dan diterima secara jelas oleh para pelaksana ADD di tingkat desa. Namun demikian terkait dengan materi penyusunan laporan pertanggungjawaban, para pelaksana khususnya para sekretaris dan bendahara tim pelaksana ADD tingkat desa masih mengalami kesulitan dan memerlukan pembimbingan lebih lanjut.

\section{Sumber Daya}

Ketersediaan sumber daya dalam pelaksanaan kebijakan Alokasi Dana Desa masih kurang maksimal terutama dalam hal ketersediaan sumber daya manusia. Dari segi kuantitas, Dispermades Kabupaten Tegal menyatakan bahwa jumlah staf yang ada sampai saat sekarang masih kurang memadai dibandingkan dengan banyaknya beban tugas yang harus dilaksanakan, sedangkan dari segi kualitas, kemampuan dari Tim Pelaksana ADD Tingkat Desa dinilai masih belum mumpuni sehingga sering mengakibatkan berbagai permasalahan muncul dalam pelaksanaan kebijakan Alokasi Dana Desa. Ketersediaan sumber daya finansial dan sarana prasarana pendukung pelaksanaan kebijakan ADD di Desa Margasari Kecamatan Margasari Kabupaten Tegal sudah cukup memadai.

\section{Disposisi Pelaksana}

Pemahaman implementor mengenai pelaksanaan program ini sudah cukup baik. Implementor telah memberikan tanggapan yang baik dan positif serta mengetahui apa yang menjadi tugasnya. Tindakan yang dilakukan para pelaksana khususnya tim koordinasi tingkat kabupaten dan tim koordinasi tingkat kecamatan sudah sejalan dengan apa yang menjadi tugas dan tanggung jawabnya di lapangan.

Hal. 32 dari 81 
Namun, Tim Pelaksana ADD Tingkat Desa yang juga sebagai implementor dinilai kurang berkompeten dalam melaksanakan tugasnya karena pengaruh dari faktor SDM rendah yang dimiliki oleh perangkat di desa.

\section{Struktur Birokrasi}

Struktur birokrasi di Bidang Administrasi Pemerintahan Desa Dispermades Kabupaten Tegal sebagai pelaksana kebijakan ADD saat ini strukturnya sudah ramping dan fleksibel serta sesuai dengan apa yang telah ditentukan dalam perbup. Terjalin kerjasama yang baik dan pembagian tugas serta tanggung jawabnya masing-masing, koordinasi antar pegawai juga dapat berjalan dengan lancar.

Selain itu, telah ada pembentukan struktur organisasi pelaksana ADD tingkat desa sesuai dengan petunjuk teknis ADD yang dikeluarkan oleh Bupati. Kerja sama antar tim pelaksana ADD berjalan dengan baik dan tidak ada konflik. Intensitas koordinasi di tingkat desa tinggi hanya antar perangkat desa, sedangkan koordinasi dengan anggota lain di luar perangkat desa dinilai masih rendah.

\section{PENUTUP}

\section{Kesimpulan}

Implementasi Kebijakan Alokasi Dana Desa di Desa Margasari belum sepenuhnya dapat berjalan dengan optimal dimana hasil dari kegiatan ini belum dapat mencapai beberapa tujuan yang telah tercantum dalam Peraturan Bupati Tegal Nomor 2 Tahun 2017.

Dari lima indikator implementasi Kebijakan Alokasi Dana Desa ini, tiga diantaranya masih dinilai belum baik yaitu berdasarkan keterlibatan masyarakat dalam proses perencanaan dan pengalokasian ADD, pelaporan dan pertanggungjawaban, dan kemanfaatan ADD untuk kemandirian desa. Sedangkan penilaian yang sudah baik ada dalam indikator kesesuaian alokasi dengan pedoman, tupoksi tim koordinasi tingkat kabupaten dan tingkat kecamatan.

Terdapat faktor pendorong dalam implementasi Kebijakan Alokasi Dana Desa di Desa Margasari sumber daya finansial, sarana prasarana, konsistensi penyampaian informasi, pemahaman pelaksana, struktur organisasi dan kerja sama antar para pelaksana. Faktor penghambatnya yaitu kualitas sumberdaya 
manusia, minimnya kegiatan sosialisasi, tindakan pelaksana yang tidak sesuai dengan ketentuan yang berlaku dan intensitas koordinasi diantara para pelaksana kebijakan yang dinilai masih rendah.

\section{Rekomendasi}

Rekomendasi disini berkaitan dengan belum optimalnya implementasi Kebijakan Alokasi Dana Desa di Desa Margasari. Berikut rekomendasinya :

1. Kegiatan sosialisasi kebijakan ADD secara umum perlu lebih diintensifkan sampai dengan tingkat Desa dan untuk materi pembuatan laporan pertanggungjawaban perlu diadakan pelatihan atau pendampingan khusus.

2. Petunjuk Teknis ADD perlu mengatur tentang mekanisme penyusunan dokumen rencana penggunaan ADD yang lebih partisipatif.

3. Dispermades Kabupaten Tegal perlu melakukan koordinasi rutin secara berkala kepada Tim Koordinasi ADD Tingkat Kecamatan baik melalui pertemuan langsung atau dengan memanfaatkan perantara media komunikasi.

4. Peningkatan pengawasan terhadap kinerja Tim Pelaksana ADD Tingkat Desa oleh pihak kecamatan sebagai upaya untuk mendorong komitmen pelaksana tingkat desa agar dapat mematuhi semua aturan dan jadwal kegiatan yang telah ditentukan.

5. Perlunya dibuat suatu aturan standar ketercapaian hasil yang harus dicapai terhadap kinerja lembaga kemasyarakatan dan perangkat desa agar dapat mengetahui tingkat ketercapaian tujuan kebijakan ADD dalam meningkatkan kemampuan dan profesionalisme aparatur pemerintahan desa dan lembaga kemasyarakatan desa.

\section{DAFTAR PUSTAKA}

Agustino, Leo. 2008. Dasar-Dasar Kebijakan Publik. Bandung: Alfabeta

Dwijowijoto, Riant Nugroho. 2008. Public Policy. Jakarta: PT. Elex Media Komputindo

Gunawan, Imam. 2013. Metode Penelitian Kualitatif : Teori dan Praktik. Jakarta : Bumi Aksara

Keban, Yeremias T. 2008. Enam Dimensi Strategis Administrasi Publik : Konsep, Teori dan Isu. Yogyakarta : Gava Media

Hal. 34 dari 81 
Moleong, J. Lexy. 2010. Metodologi Penelitian Kualitatif. Bandung : PT Remaja Rosdakarya

Mulyadi, Deddy. 2015. Studi Kebijakan Publik dan Pelayanan Publik. Bandung: Alfabeta

Rozaki, Abdur, dkk. 2004. Memperkuat Kapasitas Desa dalam Membangun Otonomi.Yogyakarta : IRE dan Ford Fondation

Subarsono, AG. 2005. Analisis Kebijakan Publik Konsep, Teori dan Aplikasi. Yogyakarta : Pustaka Pelajar

Sugiyono, 2015. Metode Penelitian Kuantitatif Kualitatif dan R\&D.Bandung : Alfabeta

Suharto, Edi. 2005. Membangun Masyarakat Memberdayakan Masyarakat. Bandung: PT. Refika Aditama

Suwitri, Sri. 2011. Konsep Dasar Kebijakan Publik. Semarang: Badan Penerbit Universitas Diponegoro

Winarno, Budi. 2007. Kebijakan Publik : Teori dan Proses. Jakarta : PT. Buku Kita

Yani, Ahmad. 2008. Hubungan Keuangan antara Pemerintah Pusat dan Daerah di Indonesia. Jakarta : Rajawali Press

\section{Sumber regulasi}

Undang-Undang Nomor 6 Tahun 2014 Tentang Desa

Peraturan Bupati Tegal Nomor 33 Tahun 2015 Tentang Pedoman Pengelolaan Keuangan Desa

Peraturan Bupati Tegal Nomor 2 Tahun 2017 Tentang Tata Cara Pengalokasian Dan Pelaksanaan serta Penetapan Lokasi dan Alokasi Dana Desa Kabupaten Tegal Tahun 2017 